\title{
TREES AND DREAMS: SYLVIA TOWNSEND WARNER, THE PASTORAL AND FANTASTIC RURALISM
}

\section{Mary Jacobs}

This article discusses Warner's transformative use of the pastoral during the inter-war period. I shall suggest that through a reworking of familiar folk-tradition references together with the evocation of a mysterious, liminal landscape, often called up by narrative dislocation, Warner develops within this inherently paradoxical genre her own subtly transgressive pastoral form: fantastic ruralism. My principal focus will be The True Heart, the novella 'The Salutation' and the long story 'Elinor Barley', though I will also refer to the more familiar Lolly Willowes. ${ }^{1}$

In 'Women as Writers', the lecture that she gave to the Royal Society of Arts in 1959, Warner refers approvingly to those writers who have 'got into literature by the pantry window'. One of the traits they have in common, she suggests, is 'a willing ear for the native tongue, for turns of phrase used by carpenters, gardeners, sailors, milliners, tinkers, old nurses, and that oldest nurse of all, ballad and folklore'(1982, p.272). It is that oldest nurse of all, and her relationship to the rural landscape, that I want to discuss, focussing on the way in which Warner shows both of them 'a willing ear' in The True Heart, 'The 
Salutation' and 'Elinor Barley'. Exploring the relationship between ballad and landscape compels me first to say something about the term 'pastoral', and then about the ideological filters through which the countryside was seen in the interwar period, when these three texts were composed.

It has become almost obligatory to open any critical discussion of the pastoral by stressing its impossibility of definition, 'a cause lost as early as the sixteenth century" (Patterson, 1987, p.7). Terry Gifford proposes three kinds of pastoral: the literary form from its classical roots onwards; any writing with 'rural' content; and the critical perspective, sometimes known as the anti-pastoral, which exposes the false idyll of 'unrealistic' rural writing (1999, pp.1 - 2). Using Gifford's helpful taxonomy, I want to stress that paradoxical quality, that tension between pastoral and non-pastoral experience, which led Warner to conclude that 'the English pastoral was a grim and melancholy thing' (1939, p.478). The inherently 'tensive structures' (Toliver 1971, p. 125) of the pastoral tradition promote an ironic perspective, often known as 'the pastoral turn', making the form as much a vehicle for social critique as for social reassurance. Thus the pastoral has been claimed by both conservative and radical traditions; while having the power to reassure or at least to promote an acceptance of the 'inevitability' of inequality, the pastoral has been equally able to facilitate social criticism as far back as Virgil ${ }^{2}$. For some commentators, 'a note of criticism is inherent in all pastoral from the beginning of its existence ... [s]atire, moralising and allegory are merely the inborn tendencies of pastoral rendered overt and explicit' (Marinelli, 1971, p.12).

A similarly multifaceted quality informs conceptions of the rural current in the inter-war period. On the one hand, 'the country' was seen as a settled and productive landscape, imbued with patriotism, spirituality and authenticity, attributes sharing a conservative sense of the importance of origins, continuity and tradition. On the other, Warner's friend J.W. Robertson Scott's account of 
rural poverty in the 1920s, England's Green and Pleasant Land: the Truth Attempted, used a quasi-sociological approach to protest at the 'Condition of Cottages', noting that the typical hamlet community was 'hovel-housed [and] physically, mentally and morally impoverished' (Robertson Scott, 1925, pp.157-158). In reminding readers of the other side of the pastoral idyll - life in 'Arcadia' revealed as drudgery; exposure of 'the truth' behind 'England's green and pleasant land' - Robertson Scott was remaining constant to the pastoral mode's interrogative, arguably subversive, properties, facilitated by 'the pastoral turn'. A further strand of ruralism evident in this period espoused masculine vagabondage, celebrating the licence of the Open Road. This can be seen as an additional aspect of the pastoral, whose first protagonists were, after all, wandering shepherds, often depicted at play. An atavistic relish for an ancient landscape, linked to a pagan sense of the divine, here underpins a refusal to be confined by the efficiencies of encroaching modernity. This refusal is nonetheless politically ambiguous. Idealisation of the open road and the tramping life is circumscribed by class and gender; it is gentlemen flâneurs who are free to 'enact' their ramblings, E. V. Lucas' The Open Road in hand, as part of a period of holiday or licensed play. (Working class or women wanderers are seen somewhat differently, associated with threat or pathos.) For some inter-war writers then, including Warner, while "the country' could be a site for social criticism on behalf of the poor and the dispossessed, it could also suggest positive ascriptions for the fleeting, the feral and the marginal, along with the more familiar comforts of a rural community celebrating harvest home. However, the question of whether or not the representation of radical rural content can be equally interrogative is more problematic. In Warner's case this is particularly interesting as she develops a fantastic ruralism from the three faces of pastoral identified above and also from properties of popular rural writing evident in the period. Elements of each of these 'versions' are 
evident in Warner's transgressive pastoral, but with significant gendered and class inflections of her own.

Empson's famous description of the pastoral as 'a puzzling form which looks proletarian but isn't' (1986, p.6), takes us back to Warner's embodiment of 'ballad and folklore' as a female proletarian: 'that oldest nurse of all'. A friendly acquaintance of Warner's at the time when 'Elinor Barley', 'The Salutation' and The True Heart were written, Empson published Some Versions of Pastoral just a few years later in 1935. There, amongst much else, he discusses the pastoral's respect for 'the humble thing' (1986, p.21). Virgil had remarked in the Georgics on the poet's duty to accord due honour to the rural humble thing: "

I'm well aware how great

A task it is by mastery of words

To invest such humble things with dignity

(Bk. 3, lines 289-291 in Virgil, 1982, p.108).

Empson's discussion of pastoral as the humble thing refers to its interest in representing those located outside power who may yet speak truth unto it: 'the fool sees true'. Empson cites pastoral's 'mystical respect for poor men, fools and children' (1986, p.10). He doesn't mention women, though he may of course have felt that they were embraced within these categories. However, Warner's explorations of the relationships between the countryside, the pantry window and the ballad form are particularly concerned with gendered aspects, emphasising (older) women's work and women's lore. They act as complex and sometimes subversive commentaries on the assumptions of the popular ruralism of the period.

Recall Lolly, reborn as Laura Willowes in Great Mop: 'She was changed, and knew it. She was humbler, and more simple' (Warner, 1978, p.149). It is specifically women in Warner's pastoral writings who are the principal guardians and practitioners of an arcane knowledge about a rural past that lives on secretly under the present. Warner's representations of this principle 
include Lolly's vision of the old woman whose fruit and flowers in the little shop have the magical power to transport her to a new life; Mrs Faux in the story 'Over the Hill' (1932) 'whose kingdom was not of this world. She could cure warts, bring back a lover, overlook cattle' (1978, p.100); Rebecca Random, the mystic priestess of Opus 7 who sets out to teach God a lesson; and Mrs Leak, Laura's landlady, 'calling up' like the Witch of Endor.

Warner's most developed personification of this ancient power by far is Mrs Disbrowe in The True Heart, the pub landlady who knows 'The True Secret of England's Greatness' (1987, p.200) and who is revealed to be the authentic folk Queen of an England far older than that ruled by Victoria, R.I. Warner links Mrs Disbrowe, also figured as 'Godmother', to a specific use of the word 'good' which signals the persistent power of the 'old ways'. 'Goody', like 'Grannie', was an honorific title for a wise old woman. In The True Heart, the persistence of folk wisdom which will outlast modernity is invoked through objects associated with Mrs Disbrowe which are indeed 'the humble thing': 'having all about her, just as the linen-cupboard, the copper-kettle and the tea-caddy had, the air of being certain to last for a long time and to repay polishing, the air of being Good" (p.215). Sukey's suitability to inherit such a tradition is signalled in her devoted polishing of the 'handsome' chairs that 'Godmother' has passed on to the Mullein family; for Mrs Mullein they are merely 'old-fashioned' but for Sukey they are sacred objects, and 'old-fashioned' is a term signalling religious power. However, this emphasis on tradition is not conservative: 'Godmother ... don't hold with the clergy' (p.222), we are told, for she exemplifies a feminine folk magic much older than Anglicanism. Warner explores this religious power without irony or sentiment in Sukey's extraordinary dream-vision of her projected visit to London under the magical protection of 'Godmother'. There she sees:

Mrs Disbrowe standing where she had left her, standing patient and superb as she had 
stood in the pasture. Around her the houses of London had dwindled so that they rose no higher than her knees, and grass was growing from the pavement. (pp. 220-221)

Here Warner's subversively gendered pastoral has overpowered town, church, monarchy, even patriarchy.

In 'The Way by Which I Have Come' (1939) ${ }^{3}$, Warner describes the influence of one Mrs May, another wise older woman. Although this text dates from 1939, it's significant that her encounter with Mrs May dates back to the early 1920s, when The True Heart was inspired by Warner's experience of the Essex marshes' haunting landscape. Mrs May gave Warner lodgings in her small farm-house there, and talked to her in the evenings: 'She was an admirable talker, with the usual country long memory for local stories and local characters. And she had the less usual gift of being able to talk clearly and illuminatingly about agriculture and the problems of the small farmer' (Warner, 1939, p.476). No wonder then that Warner cites Mrs May in the same breath as Cobbett, Crabbe and the Hammonds among the rural 'cloud of witnesses' who have contributed to her political education. The experience of an obscure and older woman, transferred orally, is as valuable as the opinions of the established written commentators. Warner is invoking and celebrating a tradition here, but it is a radical one.

Anthea Trodd, commenting on the popularity of 'rural writing' between the wars, contrasts the appropriation of such material by Tory forces with the more subversive views of some women writers themselves. Stanley Baldwin's famous preface of 1928 to Mary Webb's Precious Bane emphasised the interconnectedness of Whitehall with Shropshire, the nation's continuity with its rural past and Woman's special relationship with Nature; Webb herself had stressed the tragically 'lost-andforgotten lives' (1929, p.102) of working-class rural women and, Trodd suggests, saw the countryside differently, as a "secret treasurable resource for working 
people' (1998, p.108). Of the key writers exemplifying popular ruralism in the inter-war period, Webb is probably best known today. This is partly because Webb's major works, like those of Warner herself, were reprinted in the $1970 \mathrm{~s}$ by Virago with critical introductions by feminist scholars, but also through the continuing popularity of her satirical commentator Stella Gibbons' Cold Comfort Farm (1932). John Lucas' comment about Gone to Earth (1917): 'Cold Comfort Farm has made it well-nigh impossible to look back at Mary Webb's novel with anything other than derisive laughter' (1997, p.73) does not do full justice to Webb's text. It is also insufficient to describe Webb's later work, especially the more formally interesting Precious Bane (1924) in which the novelist adopts an effective firstperson dialect narration spoken by the hare-lipped outsider Prue Sarn. While Webb's urgent, sexualised and sentimental style is certainly distant from the cool ironies of Warner, both writers stress the particularities of the rural economy and the rigours of working people's lives and labours; both emphasise the right of labouring rural women to literacy and self-expression and, significantly, the legitimacy and transformative potential of such women's response to landscape. In a key example of this process, Prue Sarn delineates an aesthetic in which women's work is celebrated and poverty is touched into glory:

The black pines stood with their arms out, dripping with hoar frost, all white-over, so that the tips of their drooping branches were like your fingers when you take them from the suds.

(Webb, 1929, p.73)

Like Lolly Willowes, like Angustias in 'The Salutation' and like Sukey Bond in The True Heart, Prue Sarn is conscious of a power older than 'religion' which resides in the landscape and can still be found by rural working women. Alone in the attic, 'which was parlour and church both to me', Prue is conscious of 'the visitation' of a 
spiritual ecstasy, 'a most powerful sweetness'. Webb is careful to distinguish this from religious orthodoxy 'there was nought in it of churches nor of ... sinning nor repenting... And it was as wilful in its coming and going as a breeze over the standing corn'; she also stresses this visitation's freedom from class and gender prescriptions: 'a woman who spent her days in sacking, cleaning sties and beast-housen, living hard, considering over fardens, should come of a sudden into such a marvel as this' (1929, pp. 62,63). Here we can associate aspects of Mary Webb's writing with the English Radical tradition of dissent, relating this aesthetic of transfigured poverty to the ecstasies of prophetesses and preachers in the English Revolution ${ }^{4}$ itself recalled by later radicals from William Cobbett to Warner herself, discussing her own political education in 'The Way by Which I Have Come'. In her own ruralist fiction, Warner takes matters further, politically and textually.

'Trees', the second book of Virgil's Georgics, stresses their numinous qualities alongside their productive properties. Gods inhabit trees; the divine, the human and the arboreal fusing together. Warner frequently identifies her wise women with trees. Recall the vision that liberated Lolly from her constrained London life: 'the lean wiry old woman' who grows fruit and flowers is figured 'as though she were a tree herself, growing out of the long grass, with arms stretched up like branches' (Warner, 1978, p.83). In The True Heart Sukey's flight from captivity 'on the earthy floor of a waggon, huddled for warmth among the green sheaves of mint and sage' (Warner, 1987, p.226) carries her through a tree-filled landscape and then carries the reader through a three-page meditation on the power of trees: 'Trees. Mysterious creatures that stay out all night ...' (p.231). Here Warner locates the secrets of the rural landscape, emphasising the arcane power beneath domestic duty and the magic of the pastoral's 'humble thing': 'at night they regain themselves and become trees once more, assuming their full stature ... then even the humblest old apple tree with a clothes-line fastened to it escapes from its drudgery into 
an arboreal aloofness' (p.232). The eponymous Elinor Barley (Warner, 2000, pp.187-240), advantageously married to a merchant, proudly associates herself with the Indian tree in her walled garden. There she sits, a farmer's daughter, but 'fancying myself a Sultaness'. Away from the country, her fortunes fall, and 'As I went I saw, in a sleepwalking, unnoticing way, that all the leaves were off my Indian tree, and I thought to myself, So it is with me' (p.224).

Surely the most remarkable of Warner's arboreal wise women is to be found in 'The Salutation' (2000, pp.1596). Angustias - it means 'Anguish' (p.31), as she explains to Mr Fortune - is the South American widow of Harry Bailey, an Englishman who'd settled in Brazil at The House of the Salutation. There she lives on alone, apart from some rather pastoral shepherds and servants. Despite her higher social status, we see her engaged in traditional crafts - making apricot brandy, sealing bottles - and dispensing wise advice to the grieving $\mathrm{Mr}$ Fortune: 'The heart is like an old dog. It barks, and lies down again' (p.93). However, the character of Angustias becomes overlaid by a further wise woman figure, which is itself interfused with the image of an ancient tree. In the church to which Angustias takes Timothy Fortune there are two Virgin Mary figures. One is the conventional Immaculate Conception, figuring Sacred Love. The dolllike appearance of the other recalls the Black Virgins of the South and is identified by Mr Fortune with 'the Love which is profane':

she was old, sad, and worldly... akin to those mad maidens whose forsaken ditties chime among the speeches of kings and warriors in old plays. "She is very old, that one," said Angustias. "They say she was carved from the timbers of one of the ships which came from Spain". 
At the story's crisis, Angustias and the Virgin doll merge, revealing their wisdom, 'steadfastness', 'proud patience and simplicity' in words that are spoken by

she who, in the guise and with the voice of Angustias, was the doll out of the church, the doll who had once been a tree in Spain, and then, in a first widowhood, a timber darkened with Atlantic salt, and then, widowed even from that existence, hewn into human shape to suit the needs of man's soul, and by man's soul finally forsaken. The running sap, the tears of ocean, the tears of man - she was dried of all of these. But loyal still to some integral pity that nourishes the universe she had borrowed flesh from his dream, and spoken.

(pp.93-94).

This extraordinary climax scandalously employs orthodox Christian doctrine - the Salutation, the Incarnation, and the Redemption - to suggest a new feminised theology which can speak comfort to a disgraced Christian missionary mourning the loss of a beloved Polynesian boy. The tree of Eden, seen by religious orthodoxy as an antitype of the Crucifixion tree, is here restored to the female line. The rusty old seal which denotes ownership by the House of the Salutation was formerly used for branding its slaves. The 'salutation' it depicted was of course that in which the Angel Gabriel hails the Virgin Mary: the Annunciation. Now though, it is a black and battered Virgin who hails a queer and profane love.

The theologically transgressive qualities of this revelation also engender the novella's formal experimentation. The appearances of the Virgin of profane love usher in and close down the text's dream sequences. These, while they locate the story in relation to its prior text, Mr Fortune's Maggot, also utterly disorientate the reader as to time, place and meaning. 
It was not happiness. Four thousand miles away, across a continent, across an ocean, was an island. And there, secure in the timelessness of all things irretrievably lost, was happiness.

The incarnation passage quoted earlier, linking Angustias with the Virgin, the Spanish ship and the ancient tree, leads $\mathrm{Mr}$ Fortune - along with the deeply unsettled reader - to the realisation that what we had understood as reality for over fifty pages has also been a dream, 'so terrible and yet so full of dark consolations... a dream spanning two days' (p.94), and which is only now ending perhaps. Thus feminine transgression precipitates textual dislocation. Similarly, it is the appearance of Mrs Disbrowe in The True Heart, 'patient and superb', which calls up Sukey's dream-vision of a London overpowered by the return of a feminised ruralism, the houses shrinking and the grass growing from the pavement.

There are many such instances in which Warner consciously fractures her texts' temporal, spatial and ontological orders, intersecting reality and dream, and these innovations, as we have seen, are frequently linked with a gendered principle at work in a rural landscape. It is this aspect of her inter-war writing that I suggest most clearly demonstrates Warner's fantastic ruralism.

What then does this mean for her use of 'that oldest nurse of all, ballad and folklore'? After all, the narrative outline of a ballad is traditional, linear and simple, its only complication likely to be a pattern of incremental repetition. The long story 'Elinor Barley' shows Warner negotiating a movement between such folk traditions and the textual experiments and gendered analyses characteristic of The True Heart and 'The Salutation'. In Some Versions of Pastoral Empson differentiates between ballads and the pastoral form. He suggests that ballads are produced by and for the people but are mostly not about them, whereas the pastoral form, though generally about the people, is not by or for them $(1986$, p.6). The pastoral can thus be appropriated by conservative forces interested 
in representing a benevolent relationship between rich and poor. However, 'Elinor Barley' enhances and complicates the spare dimensions of 'The Brisk Young Widow', its folk-song starting-point, and refuses to be contained by Empson's dichotomy. The ballad of 'The Brisk Young Widow' was collected in Somerset by Cecil Sharp in 1905; Warner couldn't have known it through Benjamin Britten's setting in Folk Songs vol. 5, since that didn't appear until the 1940s. However, it is no surprise that a musicologist who specialised in Tudor Church Music should be interested in developing a subtle, multi-layered text from a basic folk-song: this practice was familiar from the missa parodia of the fifteenth and sixteenth centuries. Missa parodia developed complex polyphonic masses from sometimes startlingly secular and simple chansons. Perhaps the most famous example is the very simple folk song of The Armed Man, used by Dufay, Josquin Desprez, and many others to produce Missa L'Homme Armé, the Mass of the Armed Man. 'The Brisk Young Widow' original ballad tells a simple tale of reversals in love, marriage and class expectations. A welldressed young widow is courted by a farmer whom she turns down as too poor to keep her - 'It's not your hogs and yows can maintain furbelows', she tells him, haughtily. The disappointed farmer warns her to beware the vagaries of fortune. The next he hears is that she has accepted 'a sooty collier' who 'soon did gain her'. Astounded at this turn of events, he vows he'll court no more brisk young widows.

From this bare outline of high and low, Warner develops a richly detailed and inventive narrative. Anthea Trodd's astute observation that Warner's poetic persona was often constructed around the anonymity of ballad, obliterating all reference to gender or personality (1998, pp.88-89), certainly can't be applied to her use of the ballad form in 'Elinor Barley'. The story is extraordinarily subtle in its detailed study of Elinor's addictive appetite for a man who works on the wharves unloading coal-ships, and the ghastly misery of her subsequent abjection. It is prescient in its subversive 
interrogation of gender roles - it is Elinor who pursues Robin Barley for sex, while he holds out for marriage and social advancement. It anticipates feminist theory in its use of the mirror to explore female desire and the split self: 'I felt a slow, icy tingle run through my flesh like something risen from the dead. My mind confused time present with time past' (p.234); it is Modernist in its selfconscious commentary on its own narrative, which must end with its narrator's execution for the murder of her husband; and it is post-modern in its energetic intertextualities (for in addition to the full and faithful use of 'The Brisk Young Widow', we find references to 'John Barleycorn is Dead', 'Robin Adair', The Woodlanders and much else). Yet 'Elinor Barley' also keeps faith with that 'oldest nurse', the ballad and folklore from which it begins, and with the pastoral elements which it incorporates. While it is indeed a ballad narrative which in its formal properties has moved far from the decorous Georgian use of folk-song, it is also - pace Empson - a ballad which is about the people, and a pastoral which is for them.

Like 'The Salutation' and 'Elinor Barley', The True Heart is 'a work upon a ground': a composition which draws life from an earlier source. As Warner later explained in 'The Way by Which I Have Come', The True Heart is a 'country story' which retells the legend of Eros and Psyche within the context of nineteenth-century rural England. But the simplicity of its narrative line is deceptive: its ballad-like contours are disrupted by passages as unsettling to the reader as the dream sequences in 'The Salutation', the temporal and spatial shifts in Lolly Willowes, and the mirrored moments in 'Elinor Barley'. The passage in which Sukey is forced to kill a cockerel by 'sticking' it (the pig-killing episode from Jude the Obscure is evoked) is-utterly transformed from the conventionalised rural violence of T. F. Powys and parts of Mary Webb's writing into a far more subtle psychological exploration, appropriately expressed in an unorthodox narration during which time is, startlingly, frozen. This temporal suspension permits the utterance of 
Sukey's long internal monologue 'Save me! ... I am like a ghost ... I am like a dream...' (Wamer, 1987, pp.67-69). This extraordinary representation of a fractured consciousness presages the birth of Sukey's new subjectivity and later politicisation in the subsequent part of the novel. Here in The True Heart Warner fuses Modernist formal elements - the representation of a fractured consciousness, vertiginous time shifts - with generic popular ruralism and with radical gender and class politics. This transformative inter-relationship emerges in the creation of fantastic ruralism.

The Essex marsh landscape is a symbolic counterpoint to the marginalised lives of Sukey the orphan girl and the rural poor; like the Chilterns in Lolly Willowes, the Essex marshes are ascribed a gendered quality. The sense of an obscured but vital female line is present in the novel in several ways: the dedication 'To My Mother Who first told me a story'; the observation in the Preface that 'Only my mother recognised the basis of the story'; and in Sukey's longing for the mother goddesses Mrs Seaborn (Venus), Mrs Disbrowe (Demeter) and Mrs Oxey (Juno). This concept returns us to my starting-point: to 'that oldest nurse of all' and her relationship to the rural landscape, and indeed, identifies the one with the other. It is subtly underscored by Warner's erotic evocation of a shifting, enchanting, feminised marsh landscape that can never be stably contained or fully at rest: "part smell of warm inland earth, part smell of the sea, melancholy as a desire - the smell of the marriage of two elements'(1987, p.14). 'Out here on the saltings she was in a secret place between two worlds': Sukey bites herself for sheer pleasure at the smell of this 'ambiguous territory' (p.26) on her skin. The instability of this beauty links shifting place to shifting time, so that 'It was dream-like indeed that she should be washing clothes and baking bread where once the fishes swam' (p.21). Just as the magical attributes of the landscape simultaneously disorientate and delight Sukey - 'small wonder that she felt astray from her proper self' (p.21) - so also will apparently settled systems of social organisation and control be called into 
question by the events of The True Heart, as they are in 'The Salutation' and 'Elinor Barley'. It is Warner's subtle treatment of the pastoral, and its manifestations in both literary form and in the figuring of landscape, which facilitate this questioning and suggest alternative possibilities, both textually and socially.

\section{NOTES}

1. Warner's diary records that she was composing 'Elinor Barley' in August 1929, 'The Salutation' in January 1930, and The True Heart, published in 1929, throughout 192728.

2. Virgil's Eclogue I, 'The Dispossessed', for instance, makes us simultaneously aware of the invitation to Arcadia and the exile from it. Eclogue $I X$, "The Road to Town', in describing the aftermath of eviction from the land, returns us to the same theme.

3. Reprinted as 'The Way I Have Come', The Journal of the Sylvia Townsend Warner Society 2007, pp.1-9.

4. See Christopher Hill, The World Turned Upside Down: Radical Ideas During the English Revolution, Harmondsworth: Penguin, 1975, on the lives and thought of women religious radicals such as Margaret Fell, (pp.42-44), and what Hill identifies as 'the democratization of God' beneath 'the surface stability of rural England'.

\section{WORKS CITED}

Empson, W. (1986) Some Versions of Pastoral. [1935] London: Hogarth Press.

Gifford, T. (1999) Pastoral. London: Routledge.

Hill, C. (1975) The World Turned Upside Down: Radical Ideas During the English Revolution. Harmondsworth: Penguin.

Lucas, J. (1997) The Radical Twenties: Aspects of Writing, Politics and Culture. Nottingham: Five Leaves Publication.

Marinelli, P. V. (1971) Pastoral. London: Methuen. 
Patterson, A. (1987) Pastoral and Ideology: Virgil to Valery. Berkeley: University of California Press.

Robertson Scott, J.W. (1925) England's Green and Pleasant Land: the Truth Attempted. Harmondsworth: Penguin.

Toliver, H. 'Pastoral Contrasts' (1971) in Bryan Loughrey, B. ed. The Pastoral Mode. (1984) London: Methuen, pp.124- 165 .

Trodd, A. (1998) Women's Writing in English: Britain 1900 - 1945. London: Longman.

Virgil, (1949) Ecologues Transl. E.V. Rieu, The Pastoral Poems. Harmondsworth: Penguin.

(1982) The Georgics. Transl. L. P. Wilkinson.

Harmondsworth: Penguin Classics.

Warner, S.T. (1939) 'The Way by Which I Have Come', The Countryman, vol. XIX, No.2, July 1939 , pp. $472-486$. (1978). Lolly Willows. London: Women's Press.

__ (1982) 'Women as Writers' [1959] in Collected Poems Manchester: Carcarnet, pp.265-274 (1987) The True Heart. London: Virago. (2000) The Salutation Horam, East Sussex: Tartarus Press.

Mary Webb (1929) Precious Bane. London: Jonathan Cape. 